CHROMOSOME NUMBERS AND MORPHOLOGY IN TRIFOLIUM

HAAKON WEXELSEN 
University of California Publications in Agricultural Sciences

Volume 2, No. 13, pp. 355-376, 4 figures in text

Issued May 12, 1928

\author{
University of California Press \\ Berkeley, CALifornia \\ Cambridge University Press \\ London, ExglaNd
}




\section{CHROMOSOME NUMBERS AND MORPHOLOGY IN TRIFOLIUM}

BY

HAAKON WEXELSEN*

\section{CONTENTS}

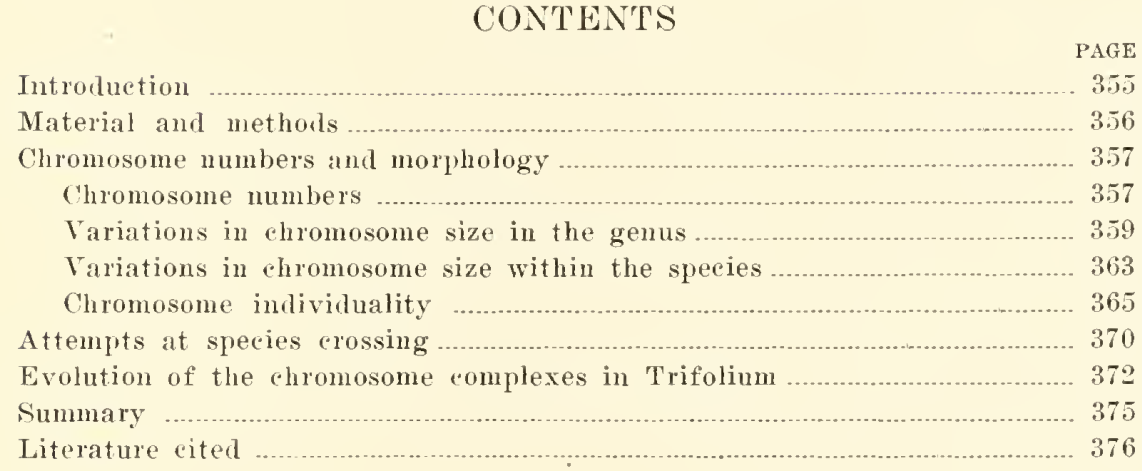

\section{INTRODUCTION}

The genus Trifolium is an outstanding genus within the family Leguminosae. It contains a large number of species which show great morphological variation and a wide geographical distribution and inchudes several very important agrieultural erops, such as $T$. pratense, T. repens, T. hybritum, T. incarnatum, and T. alexandrinum. Although considerable plant breeding work has been carried out, especially with $T$. pratense, no genetic analysis of any of these species has been made and the eytologieal investigations are of very recent date. The genetic analysis of other agricultural erop plants has rendered important service to the plant brceder, and there is crery reasoll to assume that the same will be the case with the clovers in which there are a large number of "good" genetic characters. It is of importance that the chromosome situation in these species should be known before genetic investigations are started. The results of the eytological investigations have been encouraging to the geneticist and plant breeder as they show that in the most important

\footnotetext{
* International Education Board Research Fellow, Hjellum, Norway.
} 
agrieultural plants the chromosome numbers are failly low-7 and 8 haploid, according to which 7 and 8 linkage groups are to be expected.

A genetic and eytological investigation in Trifolium was started by the writer at the Division of Genetics of the Department of Agriculture, University of California, Berkeley, in July, 1926, and carried on until December, 1927. In this paper will be ineluded only the results of the cytological investigations and the attcmpts at species crossing. I take great pleasure in thanking Professor E, B. Babeoek for laboratory facilities and give my best thanks to all the members of the staff in the Division of Geneties for help and advice. I am greatly indebted to Professor P. B. Kennedy and Mrs. A. Frederick, of the Division of Agronomy, for the material and for help in identification of the species used. Acknowledgment is also given to the International Education Board for the fellowship granted to me.

\section{MATERIAL AND METHODS}

Most of the material was grown from seeds furnished by Professor Kennedy. The seeds of the Ameriean species had been obtained cither from plants growing wild or from plants grown one generation in the grecnhouse, Plants of these species have been eompared with the specimens in the Ierbarium of the University of California and in the collection of Professor Kennedy. In the nomenclature and grouping of these species I have followed MeDermott (1910). The other speeies used were for the most part well-known cultivated speeies, with the exeeption of Trifolium glomeratum from Syzran, Russia, and $T$. subteranum, which was grown only to a seedling stage. These seeds had been obtained from the United States Department of Agriculture. The two strains of $T$. repens used were obtained from the following sources: (1) T. repens var. sylvestre, wild white elover, plants glowing wild on the campus of the University of California; (2) T. repens var. giganteum, Ladino elover; Italian white elover; seeds from Vihmorin, France. Threc strains of $T$. pratense, Italian, Late Swedish, and Canadian, were obtained from the Central Experiment Station, Ottawa, Canada.

The ehromosomes were studied in somatic divisions in root tips; in two species the reduction division in the pollen mother cells was also investigated. For the root tips the fixative of S. G. Nawasehin (Karpeehenko, 1927, p. 367) was always used. Buds for the study of pollen mother cells were fixed either in Flemming's medium or 
Nawasehin's fixative. Most of the plates were stained with Haidenhain's iron-haematoxylin, a few with iodine-gentian-violet (Huskins, 1927). For Trifolium the following procednre was found to be the best : (1) Root tips: 70 per eent aleohol ; iodine (5-10 min.); gentian violet (5-10 min.) ; iodine (30 sec.). (2) Pollen mother eells: 70 per eent alcohol; gentian-violet (5-10 min.) ; iodine (30 sec.).

Attempts were made to study the reduetion division in pollen mother eells by the aceto-earmine method, but with no sueeess. It is diffient to get the anthers out of the small buds and they are filled with inchusions (starch?) whieh apparently prevent the absorption of the fixative. The methods of emaseulation and pollination will be deseribed in the seetion on "Attempts at speeies erossing."

\section{CHROMOSOME NIMERS AND MORPHOLOGY Chromosome Numbers}

Martin (1924) eounted the ehromosomes in Trifolium pratense and $T$. repens and found the number in both to be 12, haploid. Karpeehenko (1925) examined the ehromosomes in somatie cellsroot tips-of twenty-four speeies and found the following series of diploid ehromosome numbers:

Diploid number of chromosomes $\quad 14 \quad 16 \quad 32 \quad 48$ about 80 about 130

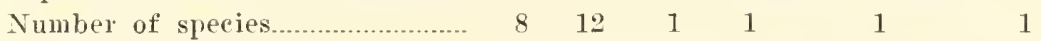

Bleier (1925) studied the reduction division in eighteen speeies and found the following series of haploid ehromosome numbers:

$\begin{array}{lllllllr}\text { Haploirl number of chromosomes } & 7 & 8 & 9 & 14 & 16 & 48 \\ \text { Number of species.......................... } & 5 & 8 & 1(?) & 2 & - & 2\end{array}$

I have obtained ehromosome numbers in ten native Ameriean speeies with the following distribution in the groups given by MeDermott (1910).

\section{Section I. Tridentatae}

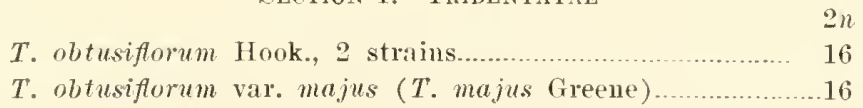

SECTION II. VARIEGATAE

T. variegatum Nutt. 16

T. wormsk joldii Lehm. $48(?)^{*}$

* But little material was available for fixation and the chromosomes were much crowded in the cells, so that the number could not be obtained with certainty. There are in figure 1c 47 bodies, one of which probably represents 2 chromosomes; 48 is very probably the correct number of cliromosomes present. 
SeCtion III. Monantheae

Section IV. Cyathiferae

T. microccphalum Pursh.

Section $\mathrm{V}$. Vesiculeae

T. fucatum Lindl.

16

T. fucatum var. virescens (T. virescens Greene) 16

Section VI, Bracteolateae

Section Vil. Mackeae

T. albopurpureum T. and G.

$2 n$

$T$. dichotomum $\mathrm{H}$, and $\mathrm{A}$.

SECTION VIII. LoNgIFOLEAE

T. reflexum Is. I.. .

Section IX. Ciliatae

T. ciliolatum Benth. ( $T$. ciliatum Nutt.) 16

'The other species eounted are:

\begin{tabular}{|c|c|c|c|c|c|}
\hline & $2 n$ & & $2 n$ & & $n$ \\
\hline T. pratense & 14 & Karpechenko & 14 & Bleier & 7 \\
\hline T. incarnatum .............. & 14 & Karpeehenko & 14 & Bleier & 7 and 8 \\
\hline$T$. repens, 2 varieties. & 32 & Karpeehenko & 32 & Bleier & 14 \\
\hline T. hybridum ........ & 16 & Karpeehenko & 16 & Bleier & 8 \\
\hline T. glomeratum ..... & 16 & & & Bleier & 7 \\
\hline T. minus $(\vartheta)^{*}$ & 32 & & & Bleier & 14 \\
\hline T. subterranum & 16 & & & & \\
\hline T. alcxandrinum & 16 & & & & \\
\hline
\end{tabular}

* The identifieation of this species is not certain, as it was not olserved in flower. T. minus ought to be studied mew to ascertain whether it has $2 \mathrm{~S}$ chromosomes is found by Bleier or 32 is found by me. If 25 is correet, this represents the only double species of the 7 series.

The eighteen species counted by the writer form the following series of diploid chromosome numbers:

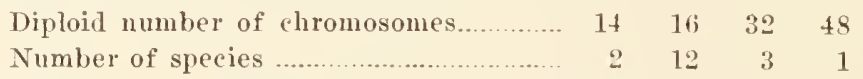

T11 Trifolium incarnatum, Karpechenko found 14 somatie ehromosomes and Bleier las plates with both 7 and 8 bivalents at heterotrpic metaphase. I found the somatie number to be 14 , whieh is probably eorreet for this species. In T. repens, Karpechenko found 32 diploid ehromoscmes and Bleier found 14 bivalents at first metaphase. Erith (1924) counted the chromosome numbers in three varieties of $T$. repens. On page 113, Erith states, "the two enltivated raees of white clover have the same number of ehromosomes as the small wild 
species." On page 92 it is stated, "The diploid nmmber of chromosomes is sixteen." Figure $62 b$ on the same page shows, however, a heterotypic metaphase with 16 bodies, and figure $62 d$ a homotypic metaphase with 16 bodies. From these figures the conchsion must be drawn that the forms investigated by Erith had 32 and not 16 as the diploid number. I found the somatic number to be $32 \mathrm{in}$ two varieties of this species. In T. montanum, Bleier found 9 bivalents at first metaphase; the count was not certain and as Karpechenko found the diploid nmmber in montanum to be 16 , it is probable that there is no species of Trifolium with 18 as the diploid number. There is now established the following series of haploid chromosone numbers in forty-three species of Trifolium:

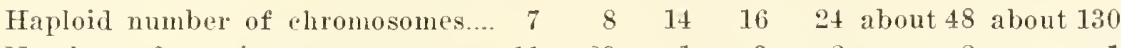

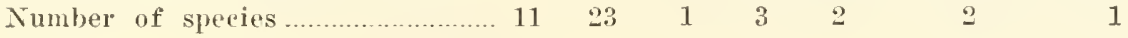

The basic numbers of this series are 7 and 8 . The 7 -series consists of single, double, and possibly higher multiple numbers; the 8-series of single, double, triple, and probably higher multiples. This is the terminology suggested by Belling (1927); the term single is used for the species with the basic number, and double and triple for species with two and three times this number, corresponding to the old terms tetraploid and hexaploid. As for the relation between chromosome numbers and the systematic classification of species, Karpechenko (1925) states: "Hence it is evident that in the process of divergence of species of clover certain chromosome changes, undiscerned by observation, have greater significance, whereas the number of chromosomes plays a subordinate rôle." The species studied by the writer give evidence in the same direction. Widely different species, such as Trifolium variegatum and T. reflexum have the same number of chromosomes, while in one group are found species with 16 and 14 chromosomes. Among the American species studied there is no representative of the 7 -series. These species form a regular multiple series, 8-16-24.

\section{Variations in Chronosome Size in the Genus}

The chromosomes in Trifolium are in general small. There is, however, a very large range of variation in length from about $1 \mu$ in T. variegatum (fig. 1d) to $4 \mu$ in T. reflexum (fig. 1b). There is a still greater difference in total chromosome volume, as illustrated by the complexes of $T$. cariegatum (fig. $1 d$ ) and $T$. dichotomum (fig. $1 k$ ). 

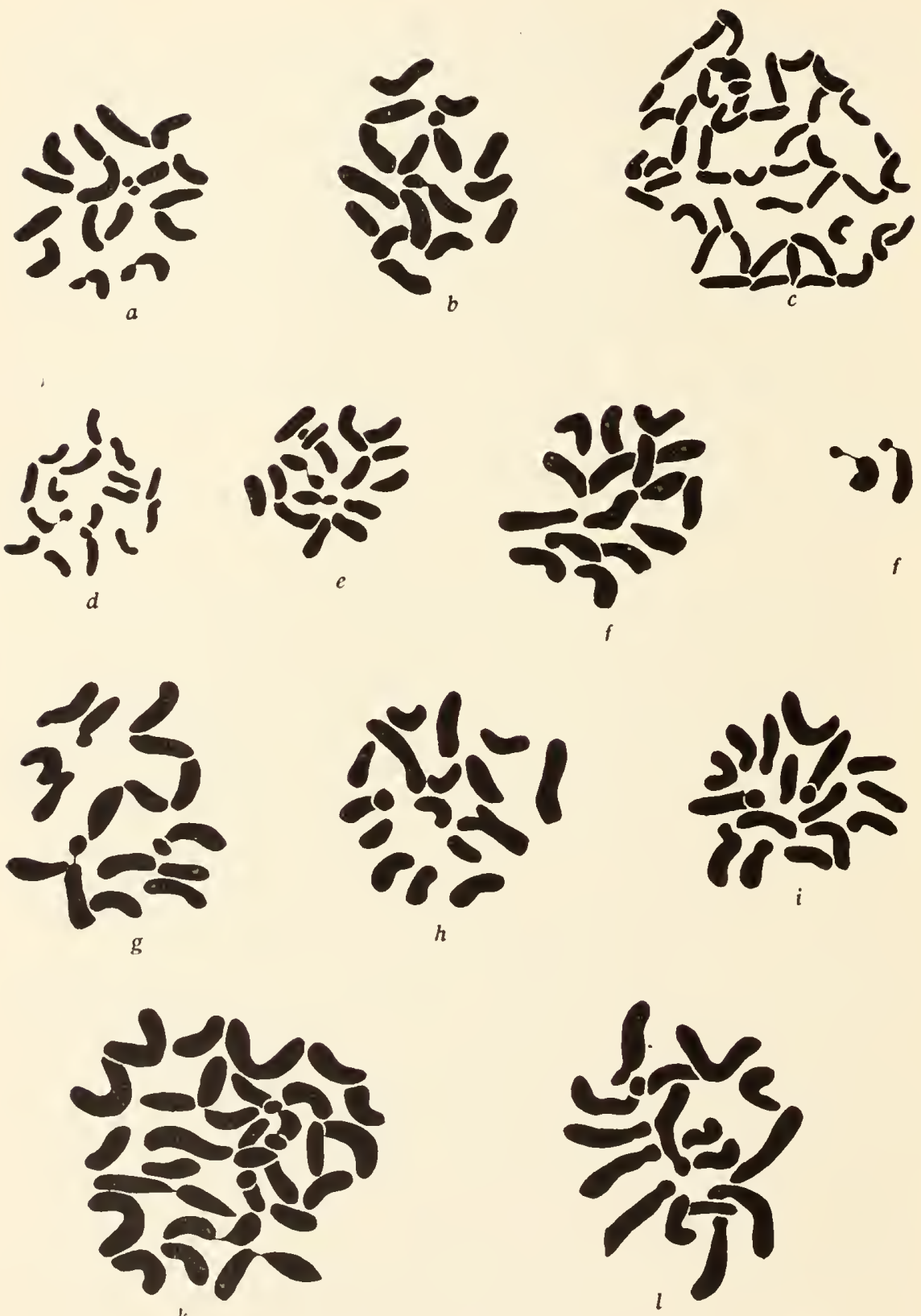

Fig. 1. Somatic metaphase figures from root tips of: $a, T$. obtusiforum: $b, T$. majus;, , T. wormsk joldii; d, T. variegatum;,$T$. mierocephalum; $f, T$. fucatum ; to the left a plate with 16 chromosomes, to the right a satellited pair from another plate; $g, T$. vircscens: $h, T$. albopurpurcum ; $i, T$. ciliolatum; $k, T$. dichotomum; $l, T$. reflexum. All drawings for this paper were made with the aid of a camera lueida. with a Zeiss 18 compensating ocular and a Leitz apochromatic $2 \mathrm{~mm}$. objective, N.A. 1.3 ; magnification 3650 ; figures not reduced; sections $7 \mu$, stained with Haidenhain's haematoxylin. 
The speeies ean be grouped as follows according to ehromosome size, the speeies in each group being arranged according to increasing size of the ehromosomes:

SMALL

1. T. variegatum

2. T. repens var. sylvestre

3. $T$. minus (?)

4. T. wormsk joldii
MEDIUMI

5. T. microcephalum

6. T. obtusiforum

7. T. glomeratum

8. Tpratense

9. T. subterranum

10. T. albopurpureum

11. T. majus

12. T. alexandrinum

13. T. repens var. giganteum

11. T. ciliolatum

1.5. T. hybridum

16. T. virescens

17. T. fucatum
LARGE

18. T. incarnatum

19. T. dichotomum

20. T. reflexum

These groups are not sharply set apart; if all the chromosomes in all the complexes are arranged aceording to size they will form a continuous series, but if one looks at the chromosome eomplexes as such, the eomplexes in the small groups are distinetly smaller, and those in the larger group larger, than the complexes in the medium group. It is not contended that these groups have any phylogenetic signifieance, but they may serve to give a pieture of the situation.

Bleier (1925) diseusses the question of ehromosome size in relation to chromosome number, nuelear size, and plant size. His diseussion is based on the size of the bivalent chromosomes at the heterotypic metaphase and on measurements of the nuelear diameter of the pollen mother cells at the synaptie stage. As is pointed out by him there is great variation in the size of the metaphase ehromosomes within a speeies. The same was found in T. alexandrinum in which a large number of metaphase plates were studied. In the same way the chromosomes at the somatic metaphase show some variation within the species (see figs. $2 a$ and $2 b$ of $T$. protense), but the variation is less than in the pollen mother cells. Bleier makes the folkowing statements regarding chromosome size in Trifolium:

1. Species with the same number of chromosomes have chromosomes of different size,

2. The nuclear volume is not dependeut upon the number of chromosomes, bnt on the mass of chromatic substance.

3. There is no correlation between chromosome number and plant size, bnt species with a larger nuclear volume have larger growth than species with small volumes. 


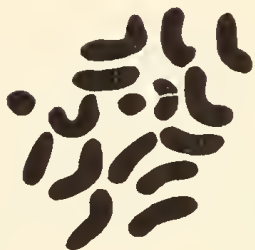

$a$
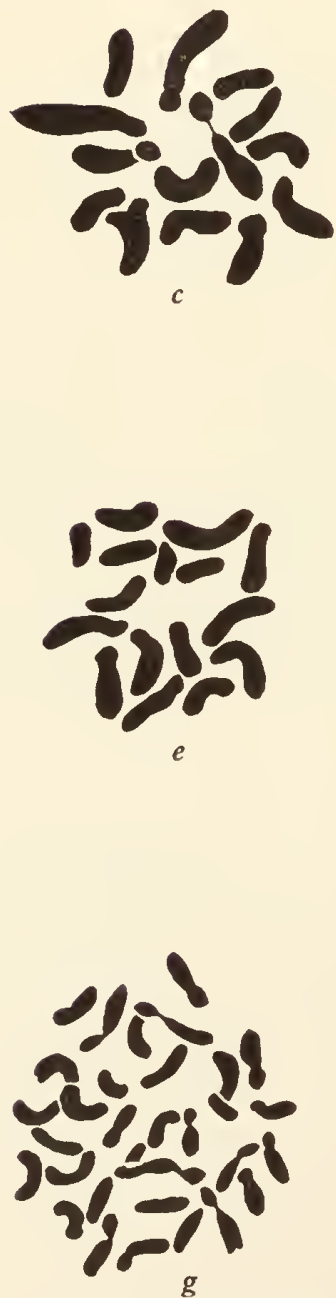

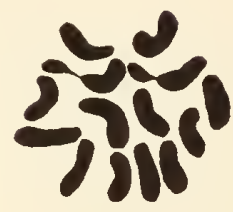

$b$
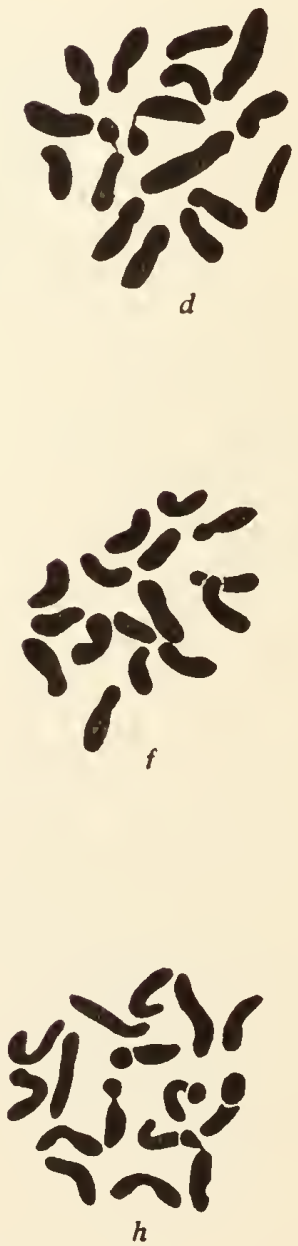

Fig. 2. Somatie metaphase figures from root tips of: $a, T$. pratense; $b, T$. pratense; $c, T$. incarnatum; $d . T$. alexandrinum; $e, T$. hybridum; $f, T$. subterranum; $g, T$. minus; $h, T$. glomeratum. Figure $2 b$ was stained with gentianviolet, the others with Haidenhain's hamatoxylin. 
The first statement is well illustrated by a comparison of the chromosomes in $T$. variegatum (fig. 1d) and T. reflexum (fig. 1l). The third statcment may hold as a general rule, but a rule to which there are many exceptions. T. obtusiflorum (fig. $1 a$ ) has 16 medium to small chromosomes, $T$. reflexum, 16 large, but the former has the largest plant size. That one must be careful in conchusions based on comparisons of chromosome size in species of the same genus is also brought out by the cases of intraspecific variability in shape and size of chromosomes discussed below.

\section{Viriations in Cirromosome Size Witinin the Species}

In Trifolium repens, two varieties were examined cytologically, $T$. repens var. sylvestre, wild white clover, and T. repens var. giganteum, Italian white clover or Lodi clover, three plants being studied in cach variety. The three plants of giganteum all had chromosomes of about the same size (fig. $3 a$, which is a metaphase plate from a root tip of plant $13 a$ ). Of the three sylvestre plants, plant $1 a$ showed very small chromosomes, $1 b$ and $1 c$ somewhat larger, but all considerably smaller than the chromosomes of $13 a$ (fig. $3 b, c, d$ ). Karpechenko (1925) studied the somatic metaphase in T. repens; he makes no statement as to the variety used but his figure shows chromosomes of the same size as those found in giganteum. Bleier (1925) and Erith (1924) both studied pollen mother cells of repens. Bleier says nothing about which rariety was studied, Erith states that she counted giganteum, hollandicum, and sylvestre, but does not say anything about differcnces in chromosome size, and it is not clcar from which variety her figures are taken. However, when the bivalcnt chromosomes in her plates $(1924$, p. $92, \times 1750)$ are compared with those of Bleier (1925, p. $618, \times 2150)$ it is clear that the chromosomes pictured by him are at least three times as large as those of Erith.

This case is very interesting because giganteum with the large chromosomes is a giant variety, sylvestre a small variety. Erith (1924) has given detailed morphological descriptions of the two varieties which correspond to the plants used by the writer. The length and breadth of the terminal leaflet in several plants of each variety were measured and the measurements for the plants studied cytologically are given below. The figures represent the average of ten measurements. 


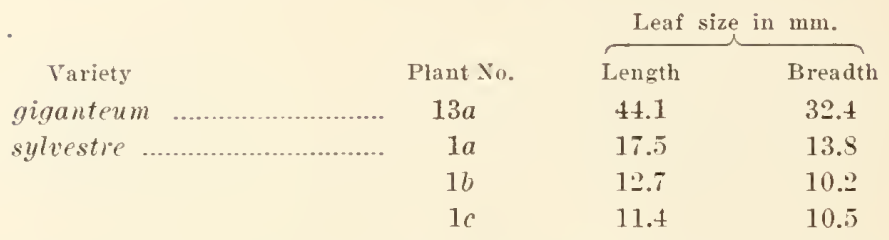

In agreement with the results of Erith, I found no differenee in flower size in the two rarieties. Apparently the increase in size in giganteum is only in the regetative parts. In aceordanee with this is the faet that the pollen is about the same size in the two rarieties, whereas the cells of the roots are considerably larger in giganteum. The same was found to hold true for the stolons by Erith (1924, pp. 110-111) who states, "In older plants the stolons of giganteum have a diameter two to three times that of sylcestre, the larger dimensions of the former being due to a greater number of individually larger cells."

The origin of giganteum is not known, but very likely it arose from sylvestre. The genetie relations of the two varieties have not been determined, but some study has been given to chromosome size in $\mathrm{F}_{1}$ hybrids. Plant $1 a$ of sylestre was crossed with plant $13 a$ of giganteum with $1 a$ as the mother plant. The $\mathrm{F}_{1}$ plants are still too voung to make possible any conclusion as to the behavior of plant size in this cross. Two somatic metaphases from $\mathbf{F}_{1}$ are pietured in figure $3 e$ and $f$. The ehromosome size is intermediate, bcing nearer to that of the giganteum parent. This result suggests that the case may be one of Mendelian inheritanee of ehromosome size. Mendelian inheritance of a ehromosomal eharaeter has bcen recorded by Leslcy and Frost (1927) in Matthiola, in which they found that one Mendelian factor was responsible for the difference in shape of the metaphase ehromosomes of the first meiotie division. Because of laek of material of the variety sylvestre, more work must be done to complete the study of chromosome size in T. repens. As this speeies is sclf-sterile, all the varicties are very heterozygous, and the plants used by the writer were very variable in morphologieal eharaeters. One might expect, therefore, to find many chromosome sizes. It is hoped that it will be possible to follow up this problem by further study of the parent varieties, the $\mathrm{F}_{1}$, and later generations. As the eytologieal work of the writer has been diseontinued, at least for some time, it seems justifiable to give a preliminary aeeount of it. 


\section{Chromosome Individulity}

Karpechenko (1925) states that he finds no chromosome individuality in the species examined by him. In contrast to this the species reported upon here exhibit many differences in chromosome size and shape within the haploir sets. The most striking of these is the presence of satellites attached to the chromosomes. In five

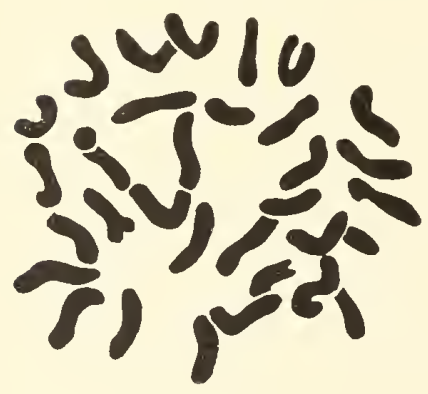

a

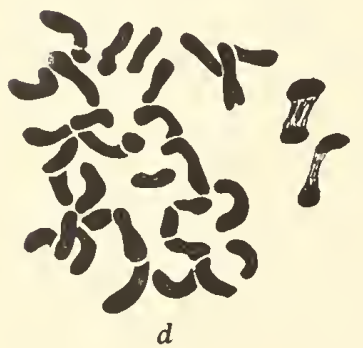

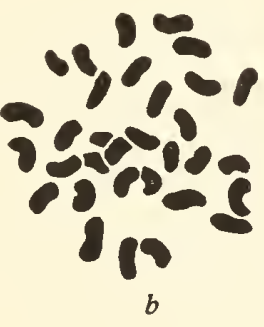

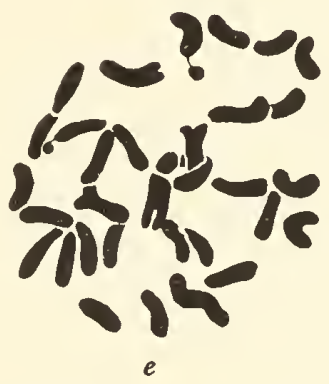

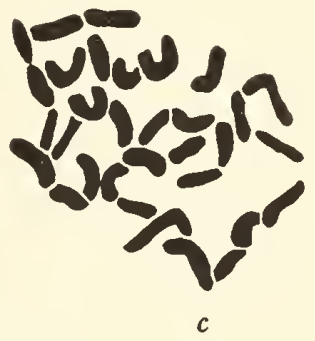

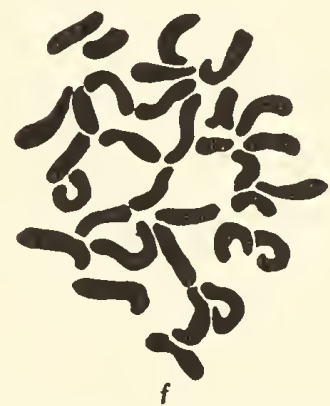

Fig. 3. Variations in chromosome size in T. repens. Somatic metaphase figures from root tips of: $a$, var. giganteum, plant no. $13 a$; $b$, var. sylvestre, plant no. $1 a$; $c$ and $d$, of plants $1 b$ and $1 c$ of the same variety; $e$, and $f$, from $F_{1}$ of the cross $1 a \times 13 a$. Stained with Haidenhain's haematoxylin.

American species, representing three sections of the genus; and in four European species, also from thrce sections, there is 1 pair of satellited chromosomes. In one spccies, Trifolium minus, there are probably 3 pairs; in $T$. repens 1 pair of satellited chromosomes was seen in one plate only (fig. $3 a$ ). Although large, the satellites in Trifolium are often difficult to observe, because the chromosomes have a tendency to stick together end to cnd, and in the same way the satellites will stick to the end of the mother chromosome. This may' 
explain why Karpeehenko did not find any satellites in T. pratense and $T$. incarnatum, in each of whieh 1 pair of conspicuous satellites was found. Of the species in whieh no satellites were found, only one, T. hybridum, has been investigated thoroughly enough to state with eertainty that it does not have satellites.

The existence of satellites was first established by S. G. Nawaschin (1912) in Galtonia. Sinee that time ther have been observed in many species and gencra. The most outstanding works are those of M. Nawaschin $(1925,1926)$ on the genus Crepis and of Taylor (1924, 1925, 1926) on Crepis, Gasteria, Allium, and other genera. In the Leguminosae, satellites have been found in Pisum, Lathyrus, and Vicia (Nawaschin, 1925; Sreshnikova, 1927).

The satellites in Trifolium are large compared with those obscrved in most other species. T. fucatum (fig. 1f) seems to have smaller satellites, while T. virescens which is nearly related to fucatum, and perhaps should be regarded as a variety (fig. 1g) of this speeies, has large satellites. This may be a ease of the same nature as that reported by Nawasehin (1926) in Crepis dioscoridis, in which he found strains differing in satellite size. It eamnot be stated with certainty that there is a real difference in satellite size in fucatum and virescens. There is some variation in satellite size within the strains and as the chromosomes of fucatum were mueh crowded on the plates only a few observations of satellites were made in this speeies. In virescens, however, many obscrvations were made, but satellites as small as those obscrved in fucatum were never scen.

A peculiar feature of these satellites is that they sometimes secm to lie frec on the metaphase plate without any visible eonncetion with any of the chromosomes, as shown in the metaphase plate of $T$. pratense (fig. 2a). The frec satellites often have a more clongated shape, resembling very much a pair of small ehromosomes. Anyone unfamiliar with the material would in sueh plates count 16 chromosomes in pratense and 18 in alexamlrinum. In these two species the reduction divisions in the pollen mother cells were also studied. In alexandrinum, many plates of the first metaphase showed 8 bivalents (fig. 4a) and, in agrecment with this, 8 chromosomes were found at second metaphase (fig. 4b). No trace of satellites was found at these stages. In $T$. pratense, both Bleicr and Karpechenko found the haploid number to be 7 in the reduction divisions of pollen mother cells. Although only a little pollen mother-cell material of $T$. pratense was arailable, several good diakinesis plates showed 7 bivalents 
(fig. $4 c$ ). As to the nature of the free satellites several interpretations can be given. It is possible that the fixation has failed to bring out the connecting thread which is really present; in this case the phenomenon has of course no significance. Against such an interpretation there is the fact that when the satellites appear to be free they are usually found far from any chromosome, on the outside of the plate, while the attached satellites usually lie in the middle of the plate and are connected with the chromosome by a short and rather thick thread. It may be, therefore, that the satellites sometimes become free in the living cell; in that case they may easily be lost in the mitotic division, giving rise to "sports" without the satellites.

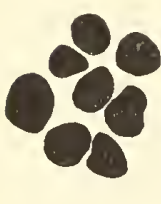

$a$
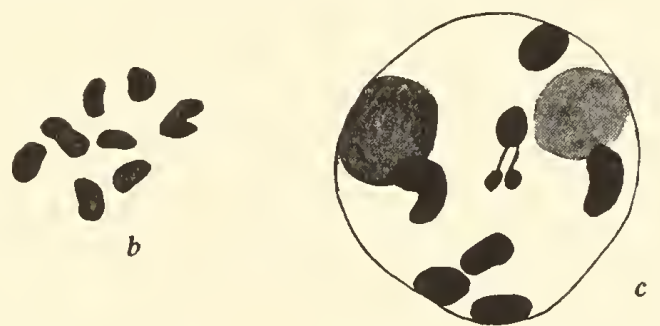

Fig. 4. a, Heterotypic division in pollen mother cell of $T$. alexandrinum; $b$, homotypic division in same; $e$, diakinesis in pollen mother-cell of $T$. pratense; to the right is shown a bivalent chromosome with attached satellites from another diakinesis plate. Figure $4 a$ was stained with Haidenhain's haematoxylin; figures $4 b$ and $e$, with iodine-gentian-violet.

This suggests the possibility that Karpechenko worked with strains of pratense and incarnatum which lacked the satellites. This does not seem likely in the case of pratense, however, as satellites were found in four strains of this species. Without making any definite conclusions as to the nature of the free satellites, it seems useful to point to the situation as a possibility for geneticists and cytologists to bear in mind when working with these species.

In some of the diakinesis plates of pratense one bivalent was seen with a pair of small bodies attached like a pair of satellites (fig. 4c). The observation was made near the close of the work and no time was available to follow it up by a further study of the reduction divisions. It seems very probable, however, that this bivalent corresponds to the one pair of satellited chromosomes to be seen in figures of somatic metaphase. No instance is known to the writer in which satellites have been obselved attached to bivalent chromosomes in the reduction division. The observation suggests that the maturation division in species with somatic satellited chromosomes should be studied, with 
the particular aim of tracing the satellites through the meiotic stages. If this could be done it would add materially to the genetic significance of satellites, as it would show that they are not only a peculiar structure of the somatic metaphase chromosomes, but are also a part of the ehromosome which is permanently differentiated out from the rest of the chromosome.

In many species of plants it has been found that certain pairs of the somatic metaphase chromosomes have definite and constant constrictions. In Trifolium the constrictions are not easily observed on account of the small size of the chromosomes. Some constricted pairs were established in several species, but an intensive study would probably reveal more eonstricted chromosomes. The constrietions are all subterminal.

In general there is not a great variation in chromosome size within the haploid sets in Trifolium. Some species, however, show conspicuous size differences, such as $T$. alexandrinum (fig. 2 $d$ ), $T$. incarnatum (fig. 2c), T. hybridum (fig. 2e), and T. reflexum (fig. 1l). The chromosome morphology of the speeics was studied with two main objectives in view:

1. In order to be able to distinguish each nomber or at least the groups of a haploid set. This is usually done in combination with a genetic analysis, by which method it is possible to assign a particular genc to a particular chromosome.

2. In order to compare the chromosome complexes in species of the same genus and by this method to study their relationship and origin. It has now eome to be used also in practical plant taxonomy to determine, in cases of doubt, whether nenrly related forms should be ranked as distinct species. The first problem has been the chief concern of the present study of chromosome morphology in species which seemed the most promising from a genctic standpoint. In these species the following features of chromosome individuality have been revealed :

T. pratense:

1 pair of satellited chromosomes, 6 pairs of about erqual size, without visible constrictions.

T. incarnatum :

1 pair of satellited chromosomes.

1 pair of large, constricted chromosomes.

2 pairs of medium, constricted chromosomes.

3 pairs of medium chromosomes without risible constrictions.

1 pair of small, constricted chromosomes. 
T. alcxandrinum:

1 pair of satellited ehromosomes.

1 pair of large, constricted ehromosomes.

3 pairs of medium, constricted ehromosomes.

2 pairs of medium ehromosomes without visible constrietions.

1 pair of small, constricted chromosomes.

The complexes in the last two species are similar but alexandrinum has one more pair of medium sized chromosomes.

T. hybridum :

6 pairs of large chromosomes, at least three pairs with constrictions.

1 pair of very small chromosomes.

1 pair of small, constricter chromosomes.

The smallest pair of chromosomes in hybridum is of the same size as the satellites of pratense, and the plates of hybridum resemble very much the plates of pratense in which the satellites have no visible conncetion with the chromosomes.

In $T$. repens, Bleier found in the first metaphase of the reduction division 4 small and 10 large bivalents. The somatic plates studied also indieate that there is one group of small and one of large chromosomes, but it is very difficult to get 32 ehromosomes, all lying flat on the plate, so that nothing ean be said with certainty as to the number of chromosomes in each group. It may be of interest to note that in the two nearly related species, hybridum and repens, we find in the former 2 pairs of small chromosomes and in the latter probably 4 pairs. In one plate of repens (fig. 3e) 1 pair of satellited chromosomes was seen, so it is probable that repens has satellited chromosomes. As hybridum has no satellites this would mean that repens has not simply twiee the complex of hybridium.

Outstanding in their chromosome morphology are also T. minus and $T$. reflexum. It is interesting that the double species, $T$. minus (32 diploid), has probably 3 pairs of satellited ehromosomes (fig. 2g) while no single species las been found with more than one pair of satellites.

T. reflexum (fig. 1l) exhibits a chromosome complex different from all other investigated species, with 5 pairs of large constrieted chromosomes and 3 pairs of smaller ehromosomes. 


\section{AT'TEMPTS AT SPECIES CROSSING}

The eases of reeorded speeies hybrids in Trifolium are listed by Karpechenko (1925) and Bleier (1925). In all eases one of the parents was a speeies with a high ehromosome number, T. pannonicum (130) or T. medium (80). Hitherto, however, no report has been given of an $\mathrm{F}_{1}$ hybrid whieh has been eytologieally investigated. Crosses were attempted between nine species in eighteen different eombinations. The material was the same as that used for eytologieal investigations. The methods used were mainly two:

1. The heads were enclosed in paper bags before any flower had opened. Emaseulation was performed when the head was about half developed. 'The flowers which were either too old or two young were eut away and in the rest of the flowers the anthers were removed with a forceps. This operation is fairly easy in the species with large flowers, but difficult in the small-flowered ones. The flowers were mostly pollinated immediately after emasculation, in some cases the next day. All the instruments used were washed in aleohol frequently during the work and only very few eases of selfing oeeurred.

2. Using plants of self-sterile species as mother plants, the pollen from other species was applied without emasculation to the stigna in flowers whieh had been bagged before opening.

Cross Nimber of flowers crossed

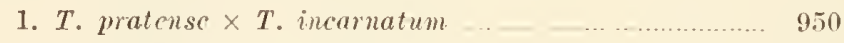

2. T. pratense $\times$ T. repens .......................... . . $3: 7$

3. T. pratense $\times$ T. hybridum ... _ . . . . . . . . . $\quad 254$

4. T. pratense $\times T$. fucatum ...... $\quad \ldots . . . . .61$

5. T. pratense $\times$ T. vireseens ............... 154

6. T. pratense $\times$ T. obtusiflorum .......................... 32

7. T. repens $\times$ T. hybridum ........................ 129

8. $T$. repens $\times T$. incarnatum ....................... 20

9. $T$. incarnatum $\times T$. alexandrinum ................. 186

10. $T$. incarnatum $\times T$. reflexum .............................. 26

11. T. inearnatum $\times T$. obtusiflorum ........................ 290

12. $T$. inearnatum $\times . T$. viresecns .............................. 9:

13. T. virescens $\times T$. fueatum .................................... 33

14. T. virescens $\times T$. obtusiflorum ................................. 6

15. T. vireseens $\times T$. reflexum .....................................

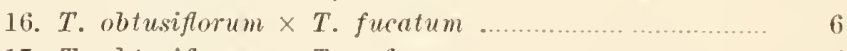

17. T. obtusiflorum $\times$ T. reflexum ............................... 15

18. $T$. reflexum $\times T$. ciliolatum ................................ 11 
With both methods the results were completely negative; a few seeds obtained by either method proved to be due to selfing. Ontside of these there seemed to be no seed development at all. Below are given the eombinations whieh were tried and the number of flowers erossed in each combination. All the crosses were made reeiproeally exeept in $4,8,10,14,15$, and 18 .

In erosses 1, 2, 3, 5, 7, 9, and 11 the number of trials is large enough to allow the statement that hybrids between these speeies are not easily obtained.

In pratense, repens, hybridum, and virescens intraspeeific crosses were made and seeds easily obtained, so the negative results are not due to faulty teehnique. T. fucatum and T. virescens are two very nearly related speeies or rarieties of the same speeies whieh did not seem to cross. The number of flowers erossed is not large, but when erossing plants within virescens seeds were easily obtained. These results do not, of eourse, allow the eonelusion that hybrids eannot be obtained between these speeies, but they suggest, in agreement with the results of other investigators, that interspeeifie hybrids are diffieult to seeure.

In case of the erosses $T$. pratense $\times T$. repens, and $T$. lubridum, respeetively, it was attempted, using the method deseribed by Martin (1913), to study the behavior of the pollen of repens and hybridum on the stigma of pratense. Flowers of pratense were emaseulated, pollinated immediately, and the stigmas pieked out for observation after 18, 24, 48, and 72 hours. The stigmas were nounted on a slide in aeeto-earmine and a slight pressure was exerted on the eoverglass to flatten the stigma. The pollen both of repens and hybridum germinated readily on the stigma of pratense, but it was not found possible to follow the pollen tube growth through the style by Martin's method. Nothing, therefore, was aseertained as to what happened to the pollen tubes. It may be that the situation is the same as in selfsterile speeies of Trifolium in whiel, when selfed, the pollen will germinate, but the pollen tube growth is too slow to reaeh the ovary. 


\section{EVOLUTION OF THE CHROMOSOME COMPLEXES IN TRIFOLIUM}

The chromosome complexes in many genera are now stndied with the aim of tracing the relationship between the species and of finding the way in which the evolution of the species has procecded. Attempts are also made to base the classification of species on chromosome morphology. For Vicia Sreshnikova (1927) has worked out a kcy based on chromosome morphology and finds that it corresponds very nearly to the key worked out by Ascherson based on external morphology. In Trifolium it is crident that there is no such parallelism in the differentiation of the chromosome complexes and of the external morphology of the species. Species which are far removed taxonomically and very different in their morphology have very similar chromosome complexes; for instance, the European species, $T$. glomeratum, and the Californian species, T. obtusifforum. On the other hand, we find nearly related species with very different chromosome complexes. The wild red clover, $T$. pratense, is very similar to $T$. medium, but the former has 14 and the latter abont 130 chronosomes. Furthermore, though the number is the same, the shape and the size of the chromosomes may be different. T. pratense and $T$. inearnatum are placed in the same subsection of the section, Eulagopus, but the chromosome complexes are very unlike. In $T$. alexandrimu and $T$. incarnatum we have two species differing in extcrnal morphology and in chromosome number (16 and 14) but very similar as regards the shape and size of the chromosomes, alexandrinum having an extra pair of medium sized chromosomes. The situation in Trifolium suggests that it will not be casy on the basis of chromosome morphology to trace the mutual relationship and origin of the species in this gems. The basis for such a study must be the possibility of establishing certain types of chromosomes, which can be identified in related species. Nawaschin's (1925) work on the genus Crepis is of this type. In ten species with 3, 4, and 5 pairs of ehromosomes he established five types of chromosomes, one of which was a satellited chromosome. In the summary Nawaschin states, "Es wrde von mir festgestellt dass dieselbe homologischen Typen und Formen der Chromosomen in den Chromosomsätzen aller untersuchten Arten hervortreten.' In Trifolium ten species at least have 
1 pair of satellited chromosomes; but considering the fact that species from very different sections have the satellites and that, on the other hand, species with and without satellites oceur in the same section, this feature does not help much in establishing any relationship between the species. It does not seem safe, either, to take chromosome size in general as an evidence of relationship, when we remember that the one species, $T$. repens, includes in itself almost the total variability in chromosome size in the genus. It is apparently only in the narrowest taxonomic groups that there is a similarity in chromosome morphology which points to common descent, and it is probably here that the study of the chromosomes may be of help to the taxonomist. Some facts pointing to this conclusion may be mentioned. $T$. variegatum in the section Variegatae has 16 very small chromosomes. In the same section is T. uormskjoldii with 48 equally small chromosomes. This suggests that these two species, in regard to their chromosomes, are more nearly related than the Californian elovers of other sections. The two nearly related forms, $T$. fucatum and $T$. virescens, have almost identical chromosome complexes. The chromosome sizes of the two related species, $T$. hybridum (16 diploid) and T. repens (32 diploid), indicate that the latter may have a complex which is twice that of the former.

The situation in Trifolium is interesting because it seems to demonstrate another type of differentiation of the chromosome complexes than is found in many other genera-studied. The genera which have been most intensively investigated eytologically are those in which interspecific hybridization has been carried out. There has been, then, a preference for genera in which interspecific hybrids are fairly easily obtained, and in which such hybrids are common in nature. This has led some investigators to emphasize hybridization as the only faetor in species differentiation, and it may perhaps not be out of the way to hold forth that there may be other ways of evolution of species. It seems only fair to do so in connection with this study in Trifolium, because all evidence suggests that hybridization has not played a dominant rôle in the differentiation of this genus. Hybrids are very rare in nature, it, indeed, ever observed, and no hybrids have been obtained in experiments. Taking into account only the external morphology of the chromosomes, in Trifolivim no certain instance of "homologous" chromosomes in different species is known, whetlrer in the form of one single chromosome, a group of chromosomes, or a complete haploid set. The existence of a satellited chromosome pair 
in many species cannot, in the opinion of the writer, be taken as evidence in this direction. The fact that the satellited chromosome pair varies in size in the different species according to the general size of the chromosome complex should make one cautious in drawing any such conclusions and this is still clearer when the distribution of the satellited ehromosomes is taken into account. In the section Euamoria we find $T$. hybridum without satellites, and $T$. glomeratum with satellites which resemble the satellites in $T$. obtusiflorum from a very different section. We are not at all justified in concluding that glomeratum and obtusiflorum have obtained their chromosome complex from a common source. In genera in which interspecific hybridization is common there have been found not only polyploid series of ehromosome numbers, but all intermediate numbers as well. A typical genus of this kind is Tiola (Clansen, 1927), which in the section Melanium has the following haploid numbers of chromosomes: $7,10,11,12,13,17,18,20,24,30$.

In Trifolium simple polyploid series withont intermediate numbers are found; $2 n=16,32,48$; and $14,28,(?)$.

It may then perhaps be justifiable to give a suggestion as to the evolution of the chromosome eomplexes in Trifolium. This genus presents a very clear demonstration of parallel variation, i.e., we find in speeies belonging to rery different sections that evolntion has proceeded along parallel lines. It seems better in aceordance with the facts to aseribe this parallel variation to parallel independent mutations than to a common descent. This is supported by the fact that we find in many species similar variations from the wild type. In speeies from different sections is found the mutant form characterized by the absence of leaf spots. In T. pratense is found a variation from the normal red flower color to white; in $T$. repens a variation from white to red, but the red and white flower color in pratense and in repens is a genetically different character. The chromosome complexes show the same picture as the morphologieal characters. The presence of one pair of satellited chromosomes should be due, then, to independent parallel mutations and not to the fact that they have been derived from a common souree. This suggestion as to the way in which the chromosome complexes in Trifolium have been differentiated is supported also by the variation in chromosome size described in $T$. repens, which is just an example of that kind of variation whieh the hypothesis supposes to take place. The great variability in ehromosone morphology in Trifolium is held to be due, 
then, to mutational changes in species isolated by interspecific sterility. It is not contended that crosses have not taken place in this genus, but it is held that the species have been thus isolated for a long time and that many mutations have oceurred.

\section{SUMLIARY}

1. Somatic chromosome numbers have been obtained in eightecn species of Trifolium, twelve of which had not been counted before; the reduction division was studied in two species.

2. The ten Ameriean species studied have the diploid numbers $16,32,48$. No representative is found of the 7 -series which is found in European species of Trifolium.

3. The chromosomes of Trifolium are in general small, but they cxhibit a great variation in size, both as to single chromosomes and to total amount of ehromatin.

4. In T. repens $\mathrm{L}$. the two varieties giganteum and sylvestre proved to have chromosomes of different size. Giganteum is a giant variety and has large chromosomes; sylvestre is a small variety and has small chromosomes. F, plants between these two varieties showed chromosomes of intermediate size.

5. Ten species from several sections of the genus have been shown to have 1 pair of satellited chromosomes and onc species probably has 3 such pairs.

6. The satellites are in some plates without visible connection with any chromosome and appear like an extra pair of small chromosomes. In a few diakinesis plates of $T$. pratense were observed bodies which must be interpreted as 1 pair of satellites attached to a bivalent chromosome.

7. On the basis of satellites, constrictions, and chromosome sizc, a scheme of chromosome morphology has bcen given for some of the species.

8. Species crosses were attempted between nine species in eighteen different combinations, but with completely negative results.

9. The suggestion is made that the diversity of chromosome complexes in Trifolium is a result of mutational changes in species which have become isolated by intersterility rather than the result of hybridization. 
BeLLiNG, J,

\section{LITERATURE CITED}

1927. The nomenelature of chromosome groups. Nature, vol. 119, p. 926. Bleier, $\mathrm{H}$.

1925. Chromosomenstudien bei der Gattung Trifolinm. Jahrb. f. wiss. Bot.,

Clausex, J. vol. $64, \mathrm{pp}, 604-36$.

1927. Chromosome number and the relationship of species in the genus ERITH, A. G.

Tiola. Annals of Bot., vol. $\$ 1$, pp. 677-71 .

1924. White elover (T. repens L.). London, Duckworth and Co. 150 pp.

Huskins, C. L.

1927. On the genetics and cytology of fatuoid or false wild oats. Jour. Genetics, vol. 15, pp. 315-6t.

KARPEChENKo, G. D.

1925. Karyologische Studien über die Gattung Trifolium. Bull. Applied Bot. and Plant Breeding, vol. 14, pp. 1-9.

1927. The produetion of polyploid gametes in hybrids. Hereditas, vol. 9, pp. 349-68.

LESLEY, M. M., and Frost, H. B. 1927. Mendelian inheritance of ehromosome shape in Matthiola. Geneties,
vol. 12, pp. $\$ 49-60$. MARTIN, J. N.

1913. The physiology of the pollen of $T$. pratense. Bot. Gaz., rol. 56, pp. 112-26.

191t. Comparative morphology of some Leguminosae. Bot. Gaz., rol. 5s, pp. $15 t-66$.

MCDERMOTT, L. F.

1910. An illustrated key to the North American species of Trifolium. San TAWASCHIN, M. Franciseo, Cunningham, Curtis and Welch. $325 \mathrm{pp}$.

1925. Morphologisehe Kernstudien der Crepis-Arten in Bezug auf die Artbildung. Zeitsehr. f. Zellforsehung und Mikroskopische Anatomie, vol. 2, pp. 98-111.

1926. Variabihtät des Zellkerns bei Crepis-Arten in Bezug auf die Artbildung. Ibid., vol. 4, pp. 171-215.

Nawaschis, S. G.

1912. Üher den Dimorphismus der Kerne in den somatischen Zellen bei Galtonia candicans. Bull. Imp. Acad. Sei. St. Petersbourg, ser. 6 , rol. 6, pp. 373-85.

SVESINIKOVA, J. $\mathrm{X}$.

1927. Karyological studies in Ticia. Bull. Applied Bot. and Plant Breeding, vol. 17, pp. 37-72.

TAYLOR, IV. R.

1924. Cytological studies on Gasteria. I. Chromosome shape and individuality. Am. Jour. Bot., vol. 11, pp. 51-59.

1925. Chromosome constrictions as distinguishing characteristics in plants. Ibid., vol. 12, pp. 23s-4t.

1926. Chromosome morphology in Fritillaria, Alstroemeria. Silphium and other genera. Ibirl., vol. 13, pp. 1s0-93. 